\title{
Clostridium ultunense sp. nov., a Mesophilic Bacterium Oxidizing Acetate in Syntrophic Association with a Hydrogenotrophic Methanogenic Bacterium
}

\author{
ANNA SCHNÜRER, ${ }^{1 *}$ BERNHARD SCHINK, ${ }^{2}$ AND BO H. SVENSSON ${ }^{3}$ \\ Department of Microbiology, Swedish University of Agricultural Sciences, S-750 07 Uppsala, ${ }^{1}$ and Department of Water \\ and Environmental Studies, University of Linköping, S-583 81 Linköping, ${ }^{3}$ Sweden, and Fakultät für Biologie,
} Universität Konstanz, D-784 34 Konstanz 1, Germany ${ }^{2}$

\begin{abstract}
A syntrophic acetate-oxidizing bacterium, strain $\mathrm{BS}^{\mathrm{T}}(\mathrm{T}=$ type strain $)$, was isolated from a previously described mesophilic triculture that was able to syntrophically oxidize acetate and form methane in stoichiometric amounts. Strain $\mathrm{BS}^{\mathrm{T}}$ was isolated with substrates typically utilized by homoacetogenic bacteria. Strain $\mathrm{BS}^{\mathrm{T}}$ was a spore-forming, gram-positive, rod-shaped organism which utilized formate, glucose, ethylene glycol, cysteine, betaine, and pyruvate. Acetate and sometimes formate were the main fermentation products. Small amounts of alanine were also produced from glucose, betaine, and cysteine. Strain $\mathrm{BS}^{\mathrm{T}}$ grew optimally at $37^{\circ} \mathrm{C}$ and $\mathrm{pH}$ 7. The $\mathrm{G}+\mathrm{C}$ content of the DNA of strain $\mathrm{BS}^{\mathrm{T}}$ was $32 \mathrm{~mol} \%$. A $16 \mathrm{~S}$ rRA sequence analysis revealed that strain BS $^{\mathrm{T}}$ was a member of a new species of the genus Clostridium. We propose the name Clostridium ultunense for this organism; strain BS is the type strain of $C$. ultunense.
\end{abstract}

Anaerobic oxidations of fatty acids to hydrogen and carbon dioxide by proton-reducing bacteria are, from a thermodynamic point of view, very unfavorable reactions (38). Under standard conditions, these hydrogen-producing reactions are all endergonic. However, standard conditions are not the conditions that occur in most natural anaerobic environments; at a very low partial pressure of hydrogen, like the partial pressure achieved in the presence of hydrogenotrophs, such as methanogenic or sulfate-reducing bacteria, the oxidation reaction becomes exergonic $(9,48)$. By consuming hydrogen, the hydrogenotrophs can create conditions under which the protonreducing bacteria can perform oxidations that otherwise could not yield energy; i.e., the latter organisms depend entirely on the former to fulfill their function.

Several different species of bacteria are able to oxidize fatty acids (38). Syntrophomonas wolfei degrades straight-chain fatty acids up to octanoate, forming acetate and propionate together with $\mathrm{H}_{2}$, in cocultures with either a methanogen or a sulfate reducer (25). Propionate is degraded to acetate, carbon dioxide, and $\mathrm{H}_{2}$ by Syntrophobacter wolinii in cocultures with members of the genus Desulfovibrio (5). Clostridium bryantii oxidizes fatty acids with 4 to 11 carbon atoms in associations with several different hydrogen-utilizing bacteria (43). Acetic acid is associated with the lowest levels of energy released from the fatty acids degraded in syntrophic cooperations. Thus, the partial pressure of hydrogen has to be very low for this reaction to proceed, and the energy available is influenced by the electron acceptor used. Under standard conditions, acetate oxidation coupled to methane formation releases less energy than acetate oxidation coupled to sulfate reduction $\left(\Delta G^{\circ \prime}=-31.0\right.$ $\mathrm{kJ} / \mathrm{mol}$ and $\Delta G^{\circ \prime}=-47.7 \mathrm{~kJ} / \mathrm{mol}$, respectively). The changes in free energy are also slightly greater at higher temperatures. Syntrophic oxidation of acetate has been observed with thermophilic and mesophilic cultures, as well as at moderate tem-

\footnotetext{
* Corresponding author. Mailing address: Department of Microbiology, Swedish University of Agricultural Sciences, Box 7025, S-750 07 Uppsala, Sweden. Phone: 4618 673209. Fax: 4618 673392. Electronic mail address: Anna.Schnurer@mikrob.slu.se.
}

peratures with both methanogenic and sulfate-reducing bacteria as the hydrogen-consuming organisms $(28,31,36,40,48)$.

Only one syntrophically acetate-oxidizing organism has been described previously $(19,20)$. This thermophilic bacterium was isolated from a methanogenic coculture and turned out to be a homoacetogen. Thus, it could also grow and obtain energy by reducing carbon dioxide to acetate with hydrogen (i.e., the reverse of acetate oxidation). Whether it produced or oxidized acetate depended on the hydrogen partial pressure.

In this paper, we describe the isolation and characterization of a mesophilic, syntrophic, acetate-oxidizing bacterium. This bacterium was isolated from the syntrophic, acetate-oxidizing, methanogenic triculture described previously by Schnürer et al. (40).

\section{MATERIALS AND METHODS}

Source of organisms. Strains SAR, TRX1, and $\mathrm{BS}^{\mathrm{T}}$ ( $\mathrm{T}=$ type strain) were isolated from a triculture which oxidized acetate syntrophically to methane at $37^{\circ} \mathrm{C}$ and in the presence of a high ammonium chloride concentration $(0.5 \mathrm{M})$ (40). This triculture originated from a mesophilic laboratory-scale digester fed with swine manure (4). The swine manure gave rise to high ammonium nitrogen concentrations ( 5.5 to $6.0 \mathrm{~g} /$ liter) in the digester.

Media and cultivation conditions. Three different media were used for isolation and cultivation. The bicarbonate-buffered basal medium (BM) described by Zehnder et al. (47) was modified as described by Schnürer et al. (40) except that (unless indicated otherwise) ammonium chloride was omitted. This medium was reduced with $3 \mathrm{mM} \mathrm{Na} 2 \mathrm{~S}$ and $2.8 \mathrm{mM}$ cysteine-HCl. A bicarbonate-buffered mineral medium was prepared as described by Widdel and Pfennig (46), with the following modifications: the medium was supplemented with $1 \mathrm{ml}$ of a solution containing $3 \mathrm{mg}$ of $\mathrm{Na}_{2} \mathrm{SeO}_{3} \cdot 5 \mathrm{H}_{2} \mathrm{O}$ and $4 \mathrm{mg}$ of $\mathrm{Na}_{2} \mathrm{WO}_{4} \cdot 2 \mathrm{H}_{2} \mathrm{O}$ in $12.5 \mathrm{ml}$ of $1 \mathrm{~N} \mathrm{NaOH}$, and trace element solution SL 10 was substituted for solution SL 7 (45). This medium was reduced with $1 \mathrm{mM} \mathrm{Na} \mathrm{S}_{2}$ and $50 \mu \mathrm{M} \mathrm{Na} \mathrm{S}_{2} \mathrm{~S}_{4}$. Modified reinforced clostridial medium (MRCM) was bicarbonate-buffered BM supplemented with (per liter) $10 \mathrm{~g}$ of yeast extract, $10 \mathrm{~g}$ of peptone, $1 \mathrm{~g}$ of starch, $5 \mathrm{~g}$ of meat extract (Lab Lemco powder; Oxoid, Unipath, Ltd., Hampshire, England), and $0.4 \mathrm{~g}$ of sodium acetate. The $\mathrm{pH}$ values of all media were adjusted to 7.1 to 7.4 . Sodium acetate was added at a concentration of $5 \mathrm{mM}$ to $\mathrm{BM}$ and the mineral medium as a potential carbon source. Unless indicated otherwise, cultures were grown in 120 - $\mathrm{ml}$ serum bottles containing $50 \mathrm{ml}$ of mineral medium under an oxygen-free $\mathrm{N}_{2}-\mathrm{CO}_{2}(80: 20)$ atmosphere at $37^{\circ} \mathrm{C}$ without shaking.

Isolation. Pure cultures were obtained by repeated application of the agar shake and roll tube culture methods $(14,30)$. The agar shake cultures and roll tubes were prepared with and without yeast extract $(0.5 \mathrm{~g} /$ liter $)$. For the roll tube cultures, $\mathrm{H}_{2}-\mathrm{CO}_{2}$ was used as a substrate and $50 \mathrm{mM}$ bromethanesulfonic acid was added to prevent growth of the methanogen present. Acetoin, betaine, ethylene glycol, fructose, methanol, vanillate, and formate were added from sterile stock solutions before inoculation into agar shake cultures. Culture purity 
was checked microscopically after the isolates were grown in brain heart infusion medium (Becton Dickinson Microbiology Systems, Cockeysville, Md.) at $37^{\circ} \mathrm{C}$ for 2 weeks.

Growth experiments. Strain $\mathrm{BS}^{\mathrm{T}}$ was grown in $250-\mathrm{ml}$ bottles (Dijkstra Vereenigde BV, Amsterdam, The Netherlands) containing $50 \mathrm{ml}$ of medium. Subsampling with syringes to measure turbidity was not possible because of cell lysis. This problem was overcome by mounting an inverted, $10-\mathrm{ml}$ glass tube through the butyl rubber stopper of each bottle and measuring the optical density at 600 $\mathrm{nm}$ directly by turning the bottle upside down and inserting the tube into a spectrophotometer (Novaspec II; Pharmacia LKB Biochrom, Ltd., Cambridge, England). Temperature, $\mathrm{pH}$, and salt optima were determined in bicarbonatebuffered BM supplemented with $20 \mathrm{mM}$ sodium pyruvate as the substrate. Cultures were incubated at $15,20,25,30,37,41,45$, and $55^{\circ} \mathrm{C}$ to determine the optimum temperature. The optimum $\mathrm{pH}$ was determined by incubating cultures at $37^{\circ} \mathrm{C}$ at initial $\mathrm{pH}$ values of $4.0,5.0,6.0,6.5,7.0,7.5,8.0,8.5,9.0$, and 10 . The $\mathrm{pH}$ was adjusted by adding $\mathrm{HCl}$ or $\mathrm{Na}_{2} \mathrm{CO}_{3}$. The optimum concentration of $\mathrm{NaCl}$ or $\mathrm{NH}_{4} \mathrm{Cl}$ was determined at $\mathrm{pH} 7.4$ and $37^{\circ} \mathrm{C}$ by testing concentrations of $0,0.1$, $0.2,0.3,0.4,0.5,0.6,0.8$, and $1.0 \mathrm{M}$.

Gram reaction. The Gram reaction was determined by a conventional staining technique, as well as by the $\mathrm{KOH}$ method (6). Acetobacterium woodii (gram positive) and Desulfovibrio vulgaris (gram negative) were used as the reference organisms.

Biochemical analyses. The test for formation of indole from tryptophan was performed as described by Harrigan and McCance (11). The ability to liquefy gelatin was assessed by adding $50 \mathrm{~g}$ of gelatin per liter to MRCM. Cell material was exposed to $10 \% \mathrm{H}_{2} \mathrm{O}_{2}$ and Kovács reagent (18) to test for the presence of catalase and oxidase, respectively.

Light microscopy. Phase-contrast microscopy was performed with a Zeiss Axioscope microscope equipped with a camera. Photographs were taken with 'Tmax 100 film (Kodak). The microscopic slides used for photography were prepared by coating them with a thin layer of agar $(3 \%)$. The agar was washed three to five times with redistilled water prior to melting. After the agar was applied to the slides, it was allowed to dry at room temperature for at least 1 day. The photographs were taken immediately as the bacteria were fixed to the agar.

Electron microscopy. Small drops of culture liquid were dried overnight on Formvar-coated grids to observe whole cells. The grids were then carbon coated and observed with a Philips model $\mathrm{CM} / 12$ transmission electron microscope operated at $80 \mathrm{kV}$. Prior to thin sectioning, cells were fixed in $3 \%$ glutaraldelyde- $2 \%$ paraformaldehyde in $0.1 \mathrm{M}$ cacodylate buffer ( $\mathrm{pH} 7.2$ ) for $3 \mathrm{~h}$. The cells were washed and then incubated overnight in a buffer containing $0.01 \%$ ruthenium red to visualize extracellular polysaccharides. Then the cells were washed and postfixed in $1.25 \%$ osmium tetroxide in $0.1 \mathrm{M}$ sodium cacodylate buffer for $1 \mathrm{~h}$. After washing, the samples were incubated overnight in water at $4^{\circ} \mathrm{C}$. The water was then removed, and $2 \%$ (wt/vol) warm agar was added. The agar was cut into small pieces, dehydrated in ethanol, and embedded in London resin. The resin was polymerized at $60^{\circ} \mathrm{C}$ overnight, and selected material was then sectioned by using a Reichert ultramicrotome. Electron micrographs were taken with a Philips model CM/12 transmission electron microscope operated at $60 \mathrm{kV}$.

$16 S$ rRNA analysis. A $16 \mathrm{~S}$ rRNA homology analysis was performed at the Deutsche Sammlung von Mikroorganismen und Zellkulturen, Braunschweig, Germany. The following procedure was used. Genomic DNA extraction, PCRmediated amplification of the 16S ribosomal DNA (rDNA), and purification of PCR products were carried out as described previously $(3,32,33)$. Purified PCR products were sequenced by using a Taq DyeDeoxy terminator cycle sequencing kit (Applied Biosystems, Germany). The sequence reaction mixtures were electrophoresed with an Applied Biosystems model 373A DNA sequencer. The 16S rDNA sequence obtained was manually aligned with representative sequences of members of the Clostridium-Bacillus line of descent. Pairwise evolutionary distances were computed by using the corrections of Jukes and Cantor (15). The least-squares method of De Soete (8) was used to construct a phylogenetic dendrogram from distance matrix data.

Analytical methods. Analyses of methane and methanethiol contents were performed by using gas chromatography as described by Schnürer et al. (40). Fatty acids containing less than seven carbon atoms, alcohols, pyruvate, ethylene glycol, and glucose were quantified by performing a high-performance liquid chromatography (HPLC) analysis (40). Amino acids were analyzed by HPLC (Pharmacia LKB, Bromma, Sweden) by using a $\mathrm{C}_{18}$ column (AccQ.Tag column; Waters, Milford, Mass.), a fluorescence detector (model RF-551; Schimadzu Corp., Kyuto, Japan), and AccQ.Fluor reagent (6-aminoquinolyl- $N$-hydroxysuccinimidylcarbamate) as the derivatization agent. A gradient system with two mobile phases was used; eluent A was Accq.Tag (Waters), and eluent B was $60 \%$ acetonitrile. The following gradient profile was used: at time zero, $100 \%$ eluent $\mathrm{A}$; at $0.5 \mathrm{~min}, 98 \%$ eluent $\mathrm{A}$; at $15 \mathrm{~min}, 93 \%$ eluent $\mathrm{A}$; at $19 \mathrm{~min}, 90 \%$ eluent $\mathrm{A}$; a.t $32 \mathrm{~min}, 67 \%$ eluent $\mathrm{A}$; at $33 \mathrm{~min}, 67 \%$ eluent $\mathrm{A}$; and at $34 \mathrm{~min}$, no eluent $\mathrm{A}$. The flow rate was $1 \mathrm{ml} / \mathrm{min}$, and the temperature was $37^{\circ} \mathrm{C}$. The amount of hydrogen was determined by gas chromatography as described by Örlygsson et al. (27). The amount of biomass protein was determined by the method of Lowry et al., as modified by Peterson (29).

Determination of the base composition of DNA. Late-log-phase cultures were cooled to $4^{\circ} \mathrm{C}$, harvested, and centrifuged at $12,500 \times \mathrm{g}$ for $30 \mathrm{~min}$. Cells were lysed with $1 \%$ sodium dodecyl sulfate, and DNA was obtained from the lysate by a modification of the method of Marmur (24). The purified DNA was dissolved in $0.1 \times \mathrm{SSC}(\mathrm{pH} 7)(1 \times \mathrm{SSC}$ is $0.15 \mathrm{M} \mathrm{NaCl}$ plus $0.015 \mathrm{M}$ sodium citrate). Thermal denaturation curves were determined with a model DU 650 spectrophotometer (Beckman Instruments, Inc., Fullerton, Calif.). DNAs from Lactobacillus reuteri $(\mathrm{G}+\mathrm{C}$ content, $41 \mathrm{~mol} \%)(2)$ and Lactobacillus sp. strain 11739 $(\mathrm{G}+\mathrm{C}$ content, $53 \mathrm{~mol} \%)(16)$ were used as controls. The $\mathrm{G}+\mathrm{C}$ content was determined by using the formula of Schildkraut and Lifson (37): $\mathrm{G}+\mathrm{C}$ content $=$ $2.08 T_{m}-106.4$ (for $0.1 \times \mathrm{SSC}$ ), where $T_{m}$ is the temperature at the midpoint of the sigmoidal curve.

High-resolution NMR. Cells were grown in 1 liter of MRCM containing 10 $\mathrm{mM}$ cysteine (optical density at $600 \mathrm{~nm}, 0.25$ ), centrifuged at $4^{\circ} \mathrm{C}$ and $12,500 \times$ $g$ for $30 \mathrm{~min}$, and washed with BM. The cell pellet was finally resuspended in 5 $\mathrm{ml}$ of $\mathrm{BM}$ containing $5 \% \mathrm{D}_{2} \mathrm{O}$ to provide a lock signal. Precipitated $\mathrm{FeS}$ was allowed to settle as described by Houwen et al. (13) to avoid peak broadening in the nuclear magnetic resonance (NMR) spectra. A $2.8-\mathrm{ml}$ portion of the supernatant was transferred to a 10 -ml NMR tube. The tube was sealed with a butyl rubber stopper, and the gas phase was changed to $\mathrm{N}_{2}-\mathrm{CO}_{2}$. All cell transfers and washing procedures were performed in an anoxic glove box with an $\mathrm{H}_{2}-\mathrm{N}_{2}$ (5:95) gas phase (Coy Laboratory Products, Inc.). At time zero, $0.16 \mathrm{ml}$ of $\mathrm{L}-\left[3-{ }^{13} \mathrm{C}\right] \mathrm{cys}-$ teine (99\% enriched) was added with a syringe to give a final concentration of 10 mM. ${ }^{13} \mathrm{C}$-NMR spectra were obtained at $101 \mathrm{MHz}$ with a Varian model VRX 400 instrument operated at $37^{\circ} \mathrm{C}$. Eleven runs were made over a period of $11 \mathrm{~h}$, and each run contained 1,000 transients. The pulse width was adjusted to $45^{\circ}$ (13 $\mu \mathrm{s}$ ) with a repetition time of $5.6 \mathrm{~s}$, and a walz modulator was used for broadband decoupling.

Cocultivation experiments. Cocultivation experiments were performed with isolates SAR1 and TRX1 by using BM with and without yeast extract and, in most cases, with and without $\mathrm{NH}_{4} \mathrm{Cl}(0.2 \mathrm{M})$. The $\mathrm{pH}$ of the medium was adjusted to 7.5 to 8.0 , and the cultures were incubated at $37^{\circ} \mathrm{C}$ without shaking. The hydrogen-consuming organisms used in the experiments were Methanococcus deltae DSM 2771, Methanogenium olentangyi DSM 2772, Methanoplanus limicola DSM 2279, Methanobrevibacter arboriphilus DSM 744, Desulfovibrio vulgaris DSM 644, Wolinella succinogenes DSM 1740, and methanogenic isolate MAB1 (41) from the triculture. All of the methanogenic strains used were halotolerant, and all could grow in the presence of $0.2 \mathrm{M}$ ammonium chloride. Two types of cultivation were performed in all experiments: (i) isolates SAR1 and TRX1 and the hydrogen-consuming organism were grown separately on medium containing cysteine $(10 \mathrm{mM})$, on medium containing glucose $(10 \mathrm{mM})$, and in the presence of $\mathrm{H}_{2}-\mathrm{CO}_{2}(80: 20)$, respectively. Either SAR1 or TRX1 or both SAR1 and TRX1 were transferred to the actively growing culture of the hydrogen-consuming organism once exponential growth had started. (ii) SAR1 or TRX1 or both SAR1 and TRX1 and the hydrogen-consuming organism were transferred to a new bottle containing fresh medium. The coculture experiments in which isolate $\mathrm{BS}^{\mathrm{T}}$ was used were performed in $\mathrm{BM}\left(\mathrm{pH} 7.4,37^{\circ} \mathrm{C}\right)$ reduced with either sodium sulfide and cysteine or sodium sulfide and sodium dithionite. Cells growing exponentially on ethylene glycol were transferred to actively growing cultures of methanogenic isolate MAB1. The gas phase $\left(\mathrm{H}_{2}-\mathrm{CO}_{2}, 80: 20\right)$ of the latter culture was replaced by $\mathrm{N}_{2}-\mathrm{CO}_{2}(80: 20)$, and sodium acetate was added to a final concentration of $50 \mathrm{mM}$ before the nonmethanogenic isolates (SAR1, TRX1, BS ${ }^{\mathrm{T}}$ ) were transferred to the culture containing the hydrogen-consuming organism.

Nucleotide sequence accession number. The nucleotide sequence of strain BS ${ }^{\mathrm{T}}$ $16 \mathrm{~S}$ rDNA has been deposited in the EMBL Nucleotide Sequence Database under accession number Z69293.

\section{RESULTS}

Isolation and cocultivation. The first attempt to isolate an acetate-oxidizing bacterium from the triculture was made with $\mathrm{H}_{2}-\mathrm{CO}_{2}(80: 20)$ as the substrate since the only syntrophically acetate-oxidizing bacterium described previously is a homoacetogenic bacterium that is able to use $\mathrm{H}_{2}-\mathrm{CO}_{2}$ as a substrate. Two isolates were obtained after repeated serial dilution in roll tubes containing $\mathrm{BM}, \mathrm{H}_{2}-\mathrm{CO}_{2}$ as the substrate, and bromethanesulfonic acid to inhibit the methanogen. Colony formation was poor in the absence of yeast extract, but when yeast extract was present, colonies grew readily. The bacterial cells obtained were morphologically similar to cells of strains SAR1 and TRX1, the two nonmethanogenic bacteria observed in the triculture (4). TRX1 turned out to be a saccharolytic organism that grew on several sugars and formed mainly lactate and carbon dioxide. This bacterium did not grow with $\mathrm{H}_{2}-\mathrm{CO}_{2}$ but was able to utilize the yeast extract added to the medium. Strain SAR1 grew with the cysteine added to the medium as a reducing agent and with yeast extract and probably grew on these components rather than $\mathrm{H}_{2}-\mathrm{CO}_{2}$. Pyruvate and cysteine were the only substrates found to be used by strain SAR1, and 
acetate was the main product obtained with both of these substrates; when pyruvate was the substrate, some formate was also produced. Coculture experiments performed with strain MAB1, the methanogen isolated from the triculture (41), and other hydrogen-consuming organisms were used to verify the acetate-oxidizing capacity of strain SAR1 and/or TRX1. $\mathrm{NH}_{4} \mathrm{Cl}$ was not necessary for the growth of SAR1 and TRX1, but since the triculture was growing in the presence of a high concentration of ammonium chloride $(0.4 \mathrm{M})$, we examined cocultures both with and without ammonium chloride. However, neither strain SAR1 alone nor strain TRX1 alone nor a combination of the two organisms together with isolate MAB1 or the other hydrogen-consuming organisms could degrade acetate. The addition of yeast extract $(1 \mathrm{~g} /$ liter $)$ or culture liquid $(5 \%, \mathrm{vol} / \mathrm{vol})$ from the triculture did not reestablish acetate oxidation. Since neither strain SAR1 nor strain TRX1 could oxidize acetate in the presence of any hydrogen-consuming organism, we assumed that none of these bacteria was the syntrophic acetate oxidizer and that a fourth organism may be present in the triculture. Therefore, a new isolation attempt was made with substrates other than $\mathrm{H}_{2}-\mathrm{CO}_{2}$ typically used by homoacetogenic bacteria. Agar shake cultures were prepared with the medium described by Widdel and Pfennig (46). This time, however, sodium dithionite was used as the reducing agent instead of cysteine, and yeast extract was omitted from the medium. After about 1 month of incubation, small, nearly transparent colonies appeared in the shake cultures with all substrates. Microscopic observation of the colonies revealed only one type of bacterium. After two transfers to new shake cultures, colonies were transferred to liquid ethylene glycol medium. Growth in the liquid medium occurred only if yeast extract $(0.5 \mathrm{~g} /$ /iter $)$ was present. The isolated obtained, strain $\mathrm{BS}^{\mathrm{T}}$, was morphologically similar to strain SAR1. When strain $\mathrm{BS}^{\mathrm{T}}$ was combined with methanogenic strain $\mathrm{MAB} 1$, degradation of acetate started, and methane was formed after a lag period of approximately 2 months. Cocultivation succeeded only if the medium was supplied with cysteine as the reducing agent. When the acetate concentration had decreased by 15 to $20 \mathrm{mM}$, which resulted in an approximately stoichiometric amount of methane, growth stopped. Transfer of the resulting culture to new media did not result in growth, and a new cocultivation experiment gave the same results.

Morphological and cytological properties of strain $\mathrm{BS}^{\mathrm{T}}$. Strain BS $^{\mathrm{T}}$ cells were straight or slightly curved rods with somewhat pointed ends and were 0.5 to 7 by 0.5 to $0.7 \mu \mathrm{m}$ (Fig. $1)$. This organism had a pleomorphic growth cycle. Growth started with small cells $(0.5$ to 1 by $0.5 \mu \mathrm{m})$ that were almost coccoid. During the exponential phase, longer cells ( 2 to 7 by $0.7 \mu \mathrm{m}$ ) occurred, and these cells were motile; the motion pattern (i.e., spinning around and dashing from place to place) was typical of polar flagellation. At this stage the cells usually occurred singly or in pairs. In the late exponential phase, motility was lost and long cell chains were formed (Fig. 1). Typically, one or more small, almost coccoid cells occurred between the rods or at the end of a single cell or a cell chain (Fig. 1). In the stationary phase some cells started to swell (Fig. 1). Chain formation and swelling occurred more frequently in MRCM than in mineral medium. Also, small single cells were never observed during growth in rich medium. Terminal, spherical spores were occasionally observed. Colonies in agar shake cultures were whitish, nearly transparent, disc shaped, and 0.5 to $1 \mathrm{~mm}$ in diameter. The Gram reaction as determined by both conventional staining and the $\mathrm{KOH}$ test was negative for all stages of growth. However, electron micrographs of thin sections (Fig. $2 c$ ) revealed a cell wall architecture typical of gram-positive bacteria, including a plasma mem-

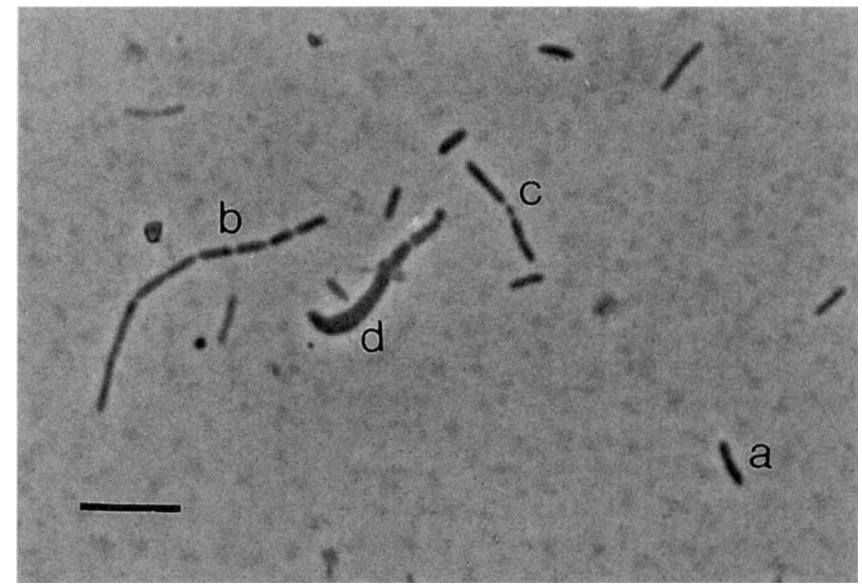

FIG. 1. Phase-contrast micrograph of $C$. ultunense $\mathrm{BS}^{\mathrm{T}}$, showing single motile rods (a), a chain of cells (b), a small cell between two rods (c), and a cell starting to swell (d). Bar $=5 \mu \mathrm{m}$.

brane layer, a thin peptidoglycan layer in the middle, and a thicker outer layer, which probably consisted of extracellular polysaccharides binding to the cell wall. Direct observation of carbon-coated samples (Fig. 2a) revealed that strain $\mathbf{B S}^{\mathbf{T}}$ had a polar flagellum and fibril-like structures, indicating that capsular material occurred on the outside of the cell. Strain BS ${ }^{\mathbf{T}}$ was catalase and oxidase negative. It produced indole from tryptophan but did not liquefy gelatin. The $\mathrm{G}+\mathrm{C}$ content of the DNA was $32 \mathrm{~mol} \%$.

Physiology. Strain $\mathrm{BS}^{\mathrm{T}}$ grew at initial $\mathrm{pH}$ values between 5.0 and 10 , and the optimum $\mathrm{pH}$ was around 7 . The temperature range for growth was 15 to $50^{\circ} \mathrm{C}$, and optimal growth occurred at temperatures around $37^{\circ} \mathrm{C}$. The highest growth rate was observed at $\mathrm{NH}_{4} \mathrm{Cl}$ concentrations around $0.1 \mathrm{M}$. Addition of $\mathrm{NaCl}$ up to a concentration of $0.5 \mathrm{M}$ had no effect on the growth rate. At concentrations of more than $0.3 \mathrm{M} \mathrm{NH}_{4} \mathrm{Cl}$ or $0.5 \mathrm{M} \mathrm{NaCl}$, the growth rate was less than the growth rate observed in the presence of no extra salts. No growth occurred in the presence of $0.8 \mathrm{M}$ sodium chloride or $0.8 \mathrm{M}$ ammonium chloride. Several substrates were tested, and growth of strain BS $^{\mathrm{T}}$ was supported only by $10 \mathrm{mM}$ formate, $10 \mathrm{mM}$ betaine, 10 $\mathrm{mM}$ glucose, $10 \mathrm{mM}$ pyruvate, $5 \mathrm{mM}$ ethylene glycol, and 10 $\mathrm{mM}$ cysteine. In these experiments cultures were grown at $\mathrm{pH}$ 7.2 to 7.4 and $37^{\circ} \mathrm{C}$ in $\mathrm{BM}$ containing substrate, $0.5 \mathrm{~g}$ of yeast extract per liter, and $5 \mathrm{mM}$ sodium acetate and in MRCM containing substrate. The formation of products (acids and $\mathrm{H}_{2}$ ) at levels greater than the levels in the controls (which contained no substrate) was used to confirm that growth occurred. The following substrates did not support growth (substrates were added at a concentration of $10 \mathrm{mM}$ unless indicated otherwise): $\mathrm{CO}$, acetoin, trimethoxybenzoate $(3 \mathrm{mM})$, vanillate ( $3 \mathrm{mM})$, mandelate $(3 \mathrm{mM})$, syringate $(3 \mathrm{mM})$, methanol, ethanol, 2-propanol, 1-butanol, 2-butanol, 1,2-propanediol, citrate, fumarate, malate, acetate $\left(\mathrm{S}^{0}, \mathrm{SO}_{4}{ }^{2-}, \mathrm{SO}_{3}{ }^{2-}, \mathrm{S}_{2} \mathrm{O}_{3}{ }^{2-}\right.$, $\mathrm{NO}_{3}{ }^{-}$, fumarate, $\mathrm{Fe}^{3+}$, glycine, and malate were used as electron acceptors and acetate was used as the electron donor), lactate $\left(\mathrm{SO}_{4}{ }^{2-}\right.$ was used as the electron acceptor), ethanolamine, hexamethyltetraamine, methylamine, dimethylamine, glycerol, fructose, glucose, mannitol, xylose, lactose, ribose, maltose, arabinose, galactose, mannose, sucrose, sorbitol, salicin, raffinose, cellobiose, proline, phenylalanine, methionine, histidine, glycine, serine, asparagine, leucine, and Casamino Acids ( 3 g/liter). In addition, $\mathrm{H}_{2}-\mathrm{CO}_{2}(80: 20 ; 0.8$ atm [ca. 81 $\mathrm{kPa}$; $\mathrm{SO}_{4}{ }^{2-}$ was used as the electron acceptor) did not support 

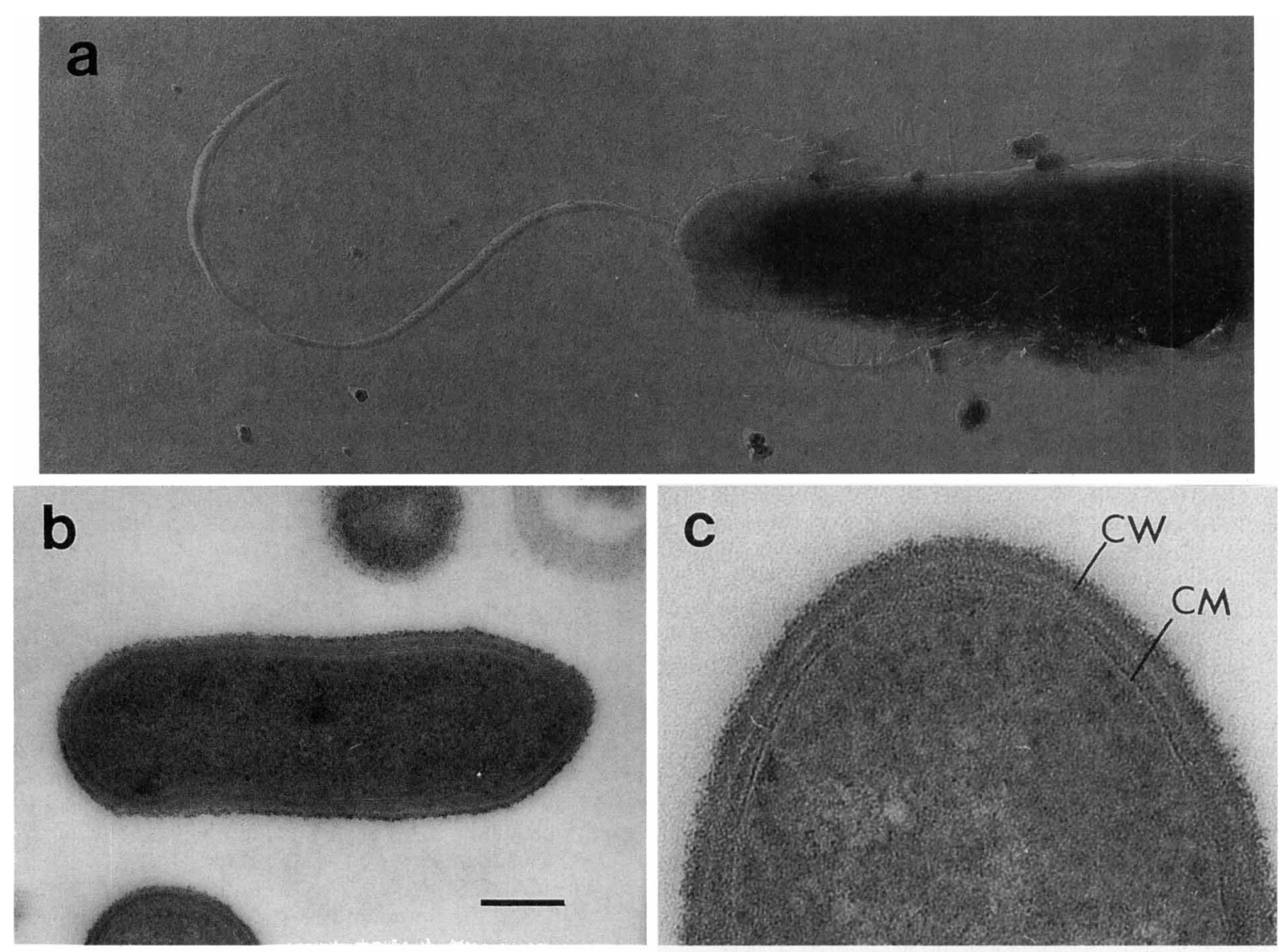

FIG. 2. Electron micrographs of $C$. ultunense BS $^{\mathrm{T}}$. (a) Negatively stained rod, showing the single polar flagellum. (b) Thin section of a cell. Bar $=0.23 \mu \mathrm{m}$. (c) Thin section showing a capsular structure, the cell wall $(\mathrm{CW})$, and the cytoplasmic membrane (CM).

growth. However, $\mathrm{H}_{2}-\mathrm{CO}_{2}$ was converted to acetate in washed, dense cell suspensions of strain $\mathrm{BS}^{\mathrm{T}}$. Yeast extract $(>0.1 \mathrm{~g} / \mathrm{li}-$ ter) was necessary for growth on the substrates mentioned above. Growth also occurred on yeast extract or MRCM. Attempts to define the medium conditions by replacing the yeast extract in BM with an amino acid solution that has been shown to stimulate the growth of Clostridium botulinum (44) were not successful. However, replacing the yeast extract with the same amount of peptone, Casitone, or tryptone resulted in a medium that supported growth.

Acetate was the main product formed from all of the substrates used by strain $\mathrm{BS}^{\mathrm{T}}$, and sometimes formate was also formed. Formate was formed from glucose, from pyruvate, and sometimes also from cysteine. Cysteine, glucose, and betaine also gave rise to small amounts of alanine. Small amounts of methanethiol were also produced from cysteine. The carbon and electron balances for all of the substrates used except ethylene glycol and betaine are shown in Table 1 . The levels of carbon recovery in the products were close to $100 \%$ with all of the substrates except cysteine. The electron balances for formate and pyruvate were almost complete, while 20 and $30 \%$ of the electrons were missing from glucose and cysteine, respectively. When ethylene glycol was used as the substrate, the only products detected by analytical methods were acetate and $\mathrm{H}_{2}$, and when betaine was used as the substrate, the only products detected were acetate, alanine, and $\mathrm{H}_{2}$. However, since the amount of betaine was not determined, the carbon and electron balances for this substrate could not be determined. The degradation of ethylene glycol was incomplete, and this reac- tion did not give rise to sufficient amounts of products for a reliable determination of the carbon and electron balances. The smell from ethylene glycol-degrading cultures indicated that acetaldehyde was formed, and accumulation of this com-

TABLE 1. Fermentation stoichiometries for C. ultunense $\mathrm{BS}^{\mathrm{T}}$ grown on selected substrates ${ }^{a}$

\begin{tabular}{lcccc}
\hline \multirow{2}{*}{ End product(s) } & \multicolumn{4}{c}{ Amt formed $(\mu \mathrm{mol} / 100 \mu \mathrm{mol}$ of substrate } \\
& consumed) with the following substrates: \\
\cline { 2 - 5 } & Glucose & Formate & Cysteine & Pyruvate \\
\hline Acetate & 197 & 24 & 88 & 102 \\
Formate & $162^{b}$ & & & $60^{b}$ \\
Alanine & 0.2 & & 1.1 & \\
$\mathrm{CO}_{2}{ }^{c}$ & 35 & 47 & 88 & 43 \\
$\mathrm{H}_{2}$ & 8.0 & & 0.40 & 2.5 \\
Cellular proteins & $-{ }^{d}$ & - & - & - \\
\hline
\end{tabular}

${ }^{a}$ Preparations were incubated at $37^{\circ} \mathrm{C}$ in $50 \mathrm{ml}$ of $\mathrm{BM}$ supplemented with yeast extract ( $2 \mathrm{~g} /$ liter $)$ and sodium acetate $(5 \mathrm{mM})$. Samples were removed for analysis in the late exponential growth phase. The levels of carbon recovery with glucose, formate, cysteine, and pyruvate were $98,95,89.1$, and $102 \%$, respectively. The oxidation-reduction indices with glucose, formate, cysteine, and pyruvate were $0.80,0.95,0.72$, and 0.94 , respectively.

${ }^{b}$ In some cases formate was not produced from glucose or pyruvate and more acetate was produced.

${ }^{c}$ In all of the experiments except the formate experiment the amount of carbon dioxide was calculated by subtracting the amount of formate from the amount of acetate. In the formate experiment the amount of carbon dioxide was calculated by doubling the amount of acetate produced.

$d_{-}$, the growth yield $(1.3 \mathrm{mg}$ of cellular protein) did not exceed the growth yield in the controls grown with only yeast extract. 


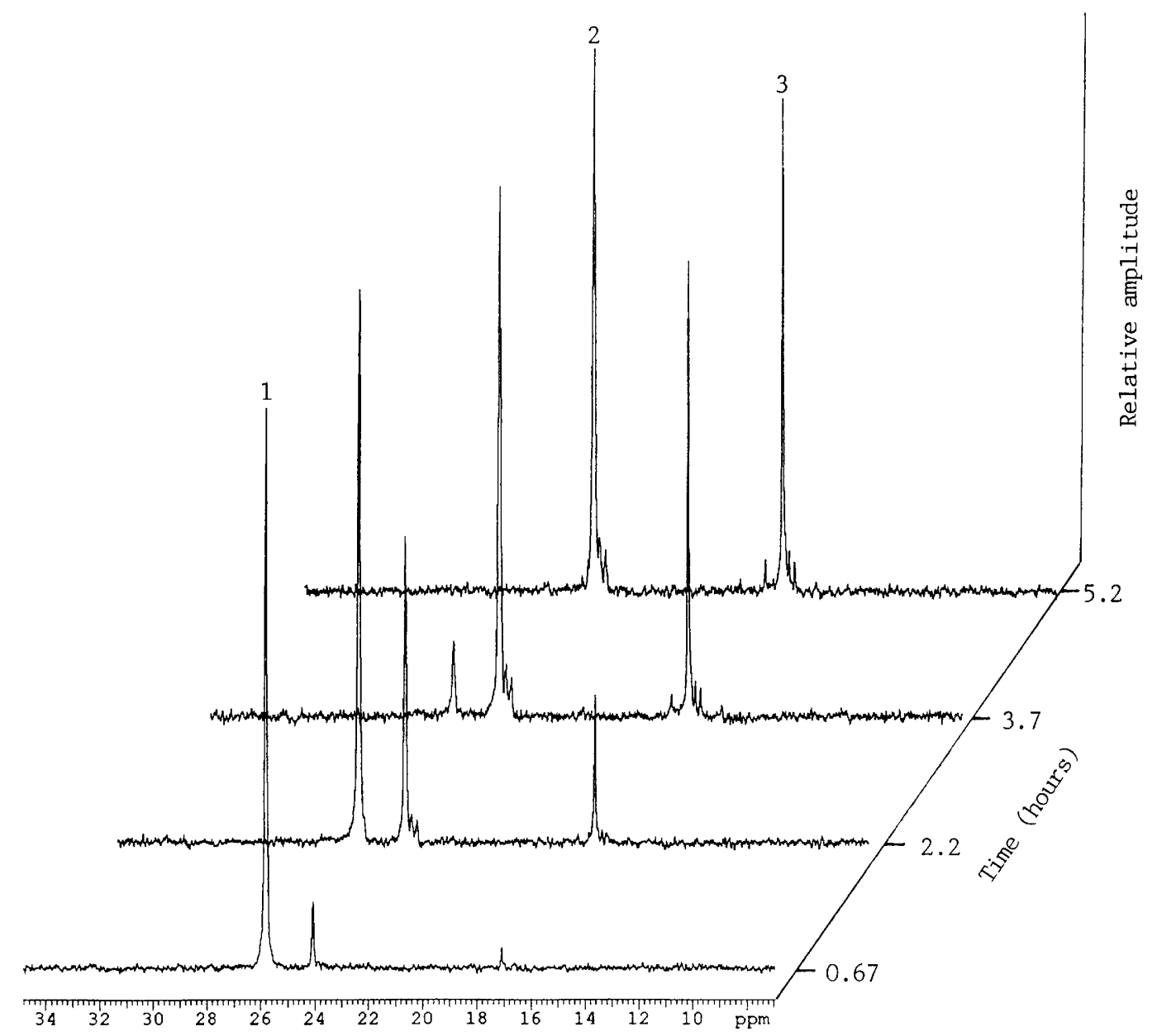

FIG. 3. Occurrence of ${ }^{13} \mathrm{C}$ label during incubation of a cell suspension of $C$. ultunense $\mathrm{BS}^{\mathrm{T}}$ with $\left[3-{ }^{13} \mathrm{C}\right]$ cysteine: chemical shifts for (C-3)-cysteine (25.8 ppm) (peak 1), (C-2)-acetate (24.1 ppm) (peak 2), and (C-3)-alanine (17.1 ppm) (peak 3).

pound to toxic concentrations may have been the reason for the incomplete degradation of ethylene glycol. Small amounts of acetate, propionate, isobutyrate, and butyrate were formed during growth on yeast extract and MRCM. The amounts of acids produced from yeast extract were different in different cultures (there was a $15 \%$ difference among triplicate cultures). Exposure to $1 \mathrm{~atm}(101.29 \mathrm{kPa})$ of $\mathrm{H}_{2}-\mathrm{CO}_{2}(80: 20)$ did not influence the fermentation of cysteine, pyruvate, or glucose. Exposure to $\mathrm{H}_{2}$ extended the lag phase of growth on glucose but had no discernable influence on the fermentation pattern once degradation had started. Strain $\mathrm{BS}^{\mathrm{T}}$ did not use acetate when $\mathrm{CO}_{2}, \mathrm{~S}^{\mathrm{O}}, \mathrm{SO}_{4}{ }^{2-}, \mathrm{SO}_{3}{ }^{2}, \mathrm{~S}_{2} \mathrm{O}_{3}{ }^{2-}, \mathrm{NO}_{3}{ }^{--}, \mathrm{Fe}^{3+}$, fumarate, glycine, or malate was the electron acceptor. The doubling time in MRCM containing pyruvate at $37^{\circ} \mathrm{C}$ and $\mathrm{pH}$ 7.2 to 7.4 was 2 days, while in BM containing yeast extract $(0.5$ g/liter) the doubling time was 5 days. Growth with other substrates was equal to or slower than growth with pyruvate.

Strains SAR1 and BS ${ }^{\mathrm{T}}$ were examined for the presence of enzymes that are active in the Wood pathway used by homoacetogenic bacteria for acetate formation (39a). Strain BS growing with ethylene glycol exhibited activities of carbon monoxide dehydrogenase, the key enzyme of the Wood pathway, and other enzymes of this pathway. Strain SAR1 growing with cysteine did not exhibit any of these enzyme activities.

16S rRNA analysis. Since strains SAR 1 and $B S^{\mathrm{T}}$ were morphologically identical, the $16 \mathrm{~S}$ rDNAs of these two organisms were sequenced. The complete sequence of the 16S rDNA of strain BS $^{\mathrm{T}}$ was determined, while a partial analysis of the strain SAR1 sequence was performed. The most variable regions were compared and were found to be identical in strains $\mathrm{BS}^{\mathrm{T}}$ and SAR1.

High-resolution NMR. The following two observations indicated that cysteine was important in the syntrophic oxidation of acetate: (i) cocultivation of strains $\mathrm{BS}^{\mathrm{T}}$ and MAB1 was successful only when cysteine was present in the medium; and (ii) only one transfer of the triculture was possible in medium containing sodium dithionite as a substitute for cysteine. Highresolution NMR with $\left[3-{ }^{13} \mathrm{C}\right]$ cysteine was performed with strain $\mathrm{BS}^{\mathrm{T}}$ to investigate the intermediates and products formed from cysteine. The spectra obtained (Fig. 3) confirmed that acetate and alanine were the main products of cysteine fermentation. No intermediates or sulfur-containing end products were observed. The peak areas indicate that more alanine was produced during conversion of $\left[3-{ }^{13} \mathrm{C}\right]$ cysteine by a washed cell suspension than during conversion of cysteine by a growing culture (Table 1). In the cell suspension, the observed acetate/ alanine ratio was 1.7 , while the ratio was 80 in the growing culture in the late logarithmic phase.

\section{DISCUSSION}

Since acetate was degraded and stoichiometric amounts of methane were formed during cocultivation of strain $\mathrm{BS}^{\mathrm{T}}$ and methanogenic isolate $\mathrm{MAB} 1$, it seems clear that strain $\mathrm{BS}^{\mathrm{T}}$ was 
the acetate-oxidizing organism in the triculture. We cannot explain why acetate oxidation ceased after degradation of ca. $20 \mathrm{mM}$ acetate or why this coculture failed to continue to grow after it was transferred to fresh medium. Strain BS ${ }^{\mathrm{T}}$ had features that are typical of the homoacetogenic bacteria since acetate was the main fermentation product formed and since carbon monoxide dehydrogenase activity was observed. The characteristic property of homoacetogenic bacteria is their ability to use carbon dioxide as an electron sink and reduce it via the Wood pathway, which involves the key enzyme carbon monoxide dehydrogenase, to acetate, the typical fermentation product. Taxonomically, the homoacetogenic bacteria constitute an extremely heterogeneous group, which includes both gram-positive and gram-negative bacteria, spore formers, both rod-shaped and coccoid bacteria, both motile and nonmotile organisms, and both mesophiles and thermophiles. Several genera are included in this group, including the genera Clostridium, Sporomusa, Acetobacterium, Acetonema, and Peptostreptococcus (39).

Strain $\mathrm{BS}^{\mathrm{T}}$ fulfills the following four criteria described by Prazmowsky in 1880 (1) for members of the genus Clostridium: these organisms (i) form endospores, (ii) exhibit only anaerobic energy metabolism, (iii) cannot carry out dissimilatory reduction of sulfate, and (iv) have a gram-positive type of cell wall. As determined by Gram staining and the $\mathrm{KOH}$ test, strain $\mathrm{BS}^{\mathrm{T}}$ has a gram-negative type of cell wall. However, thin sectioning of this bacterium revealed a gram-positive type of cell wall. It is a well-recognized fact that bacteria belonging to the genus Clostridium sometimes may react gram negative (1).

The clostridia are a very heterogeneous group of bacteria with respect to their metabolic capacities. The genus Clostridium includes saccharolytic, proteolytic species, as well as nonsaccharolytic or nonproteolytic species that metabolize one or a few substrates $(1,12)$. This genus also includes species that are able to carry out homoacetogenic $\mathrm{CO}_{2}$ reduction $(21,22)$. Strain BS $^{\mathbf{T}}$ must be considered a specialist because it can metabolize only a limited number of compounds. The carbon and electron balances for formate and pyruvate are almost complete, while for glucose and cysteine, in particular, electrons are lacking. The missing electrons are probably in yeast extract fermentation products. The requirement for yeast extract or other organic supplements is a common feature of most clostridia and acetogenic bacteria $(12,21)$. The requirement for organic supplements might explain why strain $\mathrm{BS}^{\mathrm{T}}$ grew on agar that was not supplemented with yeast extract and in liquid cultures only in the presence of yeast extract. The $\mathrm{G}+\mathrm{C}$ contents of the DNAs of clostridia range from 22 to 55 mol\%. Most of the mesophilic, homoacetogenic clostridia have relatively low DNA G+C contents ( 22 to $37 \mathrm{~mol} \%)(21,39)$; the $\mathrm{G}+\mathrm{C}$ content of the DNA of strain $\mathrm{BS}^{\mathrm{T}}$ falls in this range.

The results of the $16 \mathrm{~S}$ rDNA sequence analysis also place strain $\mathrm{BS}^{\mathrm{T}}$ in the genus Clostridium. The position of strain $\mathrm{BS}^{\mathrm{T}}$ on a phylogenetic dendrogram is shown in Fig. 4. It is clear that this strain represents an individual line and probably a new species. Strain $\mathrm{BS}^{\mathrm{T}}$ is most closely related to Clostridium hastiforme and Clostridium sp. strain BNII. C. hastiforme has the following characteristics (23): it is moderately proteolytic, nonsaccharolytic, mesophilic, gram positive, rod shaped, and motile and forms subterminal oval spores. $C$. hastiforme also has been shown to form methane and methanethiol from methionine $(26,35)$. Strain BNII has not yet been classified but is known to degrade creatine (10). We concluded that strain BS belongs to cluster XII on the basis of the results of a $16 \mathrm{~S}$ rRNA analysis performed with members of the genus Clostridium (7). This cluster is phenotypically incoherent and includes Clostridium acidiurici, Clostridium purinolyticum, C. hastiforme, "Clos-

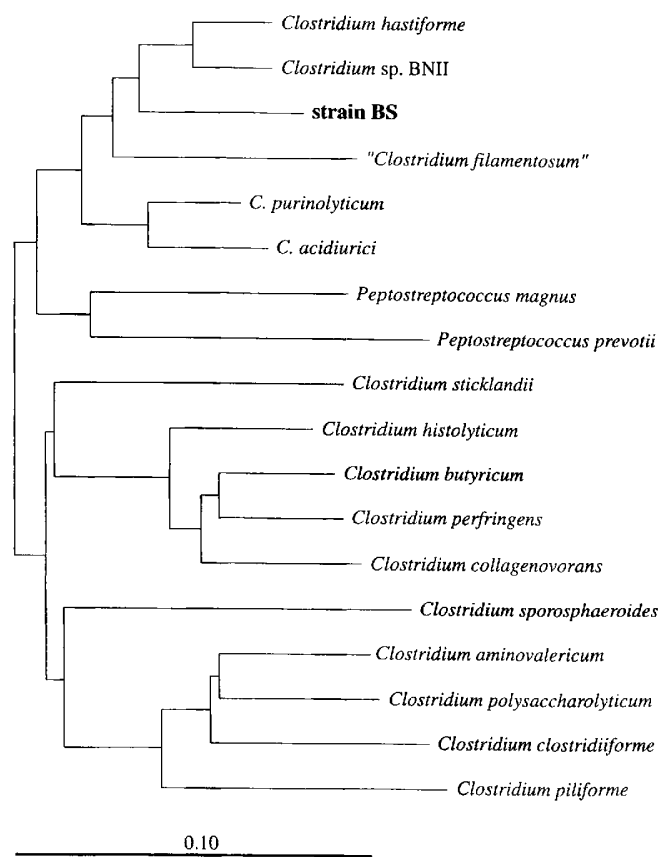

FIG. 4. Phylogenetic dendrogram showing the position of strain $\mathrm{BS}^{\mathrm{T}}$ within the genus Clostridium and in relation to other taxa. Scale bar $=10$ inferred nucleotide substitutions per 100 nucleotides.

tridium filamentosum," and Clostridium sp. strain BNII (Fig. 4). Of the clostridia in this group, $C$. acidiurici is the only acetogenic bacterium.

On the basis of the results of the $16 \mathrm{~S}$ rRNA analysis, strains SAR1 and $\mathrm{BS}^{\mathrm{T}}$ are the same organism. However, it is not possible to distinguish phylogenetically very similar strains by this method. The difference in the metabolic properties of strains BS ${ }^{\mathrm{T}}$ and SAR1 (the lack of carbon monoxide dehydrogenase activity in strain SAR1) indicates that these strains are two different organisms. On the other hand, strain SAR1 was transferred in mineral media containing yeast extract and cysteine for almost 6 months and could have lost the ability to express enzymes in the Wood pathway. A loss of one or several of the enzymes of the Wood pathway could explain why cocultivation of strain SAR1 with strain MAB1 or other hydrogenconsuming organisms was not successful. Clostridia have been shown to convert cysteine to acetate by two mechanisms that do not involve key enzymes of the Wood pathway. Clostridium propionicum degrades cysteine to propionate and acetate through acrylate as an intermediate (42). Some clostridia deaminate cysteine to pyruvate by a cysteine desulfhydralase and convert pyruvate to acetate via acetyl coenzyme A (1). Alanine is probably formed through amination of pyruvate by alanine dehydrogenase or by alanine aminotransferase, as has been shown for Pyrococcus furiosus (17).

In the triculture, an initial increase in the acetate concentration coincided with the degradation of cysteine. Therefore, it is likely that during syntrophic acetate oxidation, strain BS ${ }^{\mathrm{T}}$ expresses both the acetyl coenzyme A pathway enzymes and the cysteine-degrading enzymes. There are several possible reasons for the importance of cysteine for the functioning of the coculture of the acetate oxidizer and the methanogen, including (i) creation of a sufficiently reduced environment, (ii) the possibility that degradation of cysteine might supply strain $\mathrm{BS}^{\mathrm{T}}$ with energy necessary for the initial utilization of acetate, and (iii) dependence of MAB1 on cysteine as a sulfur source. 
TABLE 2. Comparison of morphological and physiological features of C. ultunense $\mathrm{BS}^{\mathrm{T}}$ and strain AOR, two syntrophically acetateoxidizing bacteria ${ }^{a}$

\begin{tabular}{lcc}
\hline \multicolumn{1}{c}{ Characteristic } & Strain $\mathrm{BS}^{\mathrm{T}}$ & Strain AOR \\
\hline Cell shape & Rod & Rod \\
Cell size $(\mu \mathrm{m})$ & $0.5-7 \times 0.5-0.7$ & $2-3 \times 0.4-0.6$ \\
Spore formation & + & - \\
Flagella & + & $\mathrm{ND}^{b}$ \\
Gram type & + & + \\
Capsular material & + & + \\
Utilization of the following & & \\
$\quad$ substrates: & - & + \\
$\mathrm{H}_{2}-\mathrm{CO}_{2}$ & + & + \\
Formate & + & + \\
Ethylene glycol & + & + \\
Pyruvate & + & + \\
Betaine & - & + \\
1,2-Propanediol & + & $\mathrm{ND}$ \\
Cysteine & + & $\mathrm{ND}$ \\
Glucose & Yeast extract & Yeast extract \\
Supplement required & & 60 \\
Optimum temp $\left({ }^{\circ} \mathrm{C}\right)$ & 37 & $\mathrm{ND}$ \\
Optimum pH & $6.5-8.0$ & 47 \\
G+C content (mol\%) & 32 & + \\
Carbon monoxide dehy- & + & \\
$\quad$ drogenase & &
\end{tabular}

Genus

Clostridium

Eubacterium

" Thermophilic isolate AOR was described by Lee and Zinder (19).

${ }^{b} \mathrm{ND}$, not determined.

c Supplement required for growth in mineral medium.

Although sulfide is the most common sulfur source utilized by methanogenic bacteria, other compounds, including cysteine and mercaptans, have been shown to function as sulfur sources (34).

Only one syntrophic acetate-oxidizing bacterium, strain AOR, has been described previously $(19,20,48)$. The physiological and morphological features of this bacterium are compared with those of strain $\mathrm{BS}^{\mathrm{T}}$ in Table 2. The most significant difference between these two acetate-oxidizing strains is the inability of strain $\mathrm{BS}^{\mathrm{T}}$ to grow with $\mathrm{H}_{2}-\mathrm{CO}_{2}$ as a substrate.

Description of Clostridium ultunense sp. nov. Clostridium ultunense (ul.tu.nen' se. Ull, ancient Nordic god associated with winter sports and duels; tuna, place of worship; L. ending ense; M. L. adj. ultunense, referring to ultuna, the area where the Swedish University of Agricultural Sciences is located). Straight or slightly curved rod-shaped cells are 0.5 to 7 by 0.5 to $0.7 \mu \mathrm{m}$ and occur singly, in pairs, or in chains. In the early exponential growth phase, cells are motile by means of a polar flagellum; later the cells are nonmotile. Cell chains, as well as swelling cells, are formed in the late exponential growth phase. Occasionally, terminal round spores are formed.

Gram negative, with capsular material outside the cell wall.

Colonies on agar are 0.5 to $1 \mathrm{~mm}$ in diameter, disc shaped, and whitish.

Strictly anaerobic. The substrates used as carbon and energy sources include formate, glucose, cysteine, pyruvate, betaine, and ethylene glycol. The substrates that are not utilized as carbon and energy sources include sugars other than glucose, $\mathrm{H}_{2}-\mathrm{CO}_{2}, \mathrm{CO}$, methoxylated aromatic compounds, alcohols, and all amino acids except cysteine. The main fermentation product is usually acetate, but sometimes formate is also formed in roughly the same amount. Small amounts of alanine are formed from cysteine and betaine. Sulfate, sulfite, thiosulfate, sulfur, nitrate, fumarate, malate, glycine, and ferric ion are not used as electron acceptors. Acetate is oxidized in the presence of a hydrogen-utilizing methanogenic bacterium.

Catalase and oxidase negative. Produces indole from tryptophan and does not liquefy gelatin.

Moderate growth occurs in mineral medium supplemented with yeast extract; better growth occurs in modified IRCM mineral medium supplemented with yeast extract, peptone, starch, and Lab Lemco powder. Growth in mineral medium depends on the presence of yeast extract, peptone, Casitone, or tryptone $(>0.1 \mathrm{~g} /$ liter $)$.

$\mathrm{pH}$ range, 5 to 10 . The optimum $\mathrm{pH}$ is around 7.0 .

Temperature range, 15 to $50^{\circ} \mathrm{C}$. The optimum temperature is $37^{\circ} \mathrm{C}$.

The $\mathrm{G}+\mathrm{C}$ content of the DNA is $32 \mathrm{~mol} \%$.

Habitat: anaerobic digester sludge.

The type strain is strain BS, which has been deposited in the Deutsche Sammlung von Mikroorganismen und Zellkulturen, Braunschweig, Germany, as strain DSM 10521.

\section{ACKNOWLEDGMENTS}

We thank Geoffrey Daniel for taking the electron micrographs and Rolf Andersson for performing the NMR analysis.

This work was supported by contracts E.EG 8379-302 and E.EG 8379-308 with the Swedish Council of Natural Sciences, by grant SF193 from the Royal Academy of Forestry and Agriculture, and by the Biological Hydrogen Production Program of the Bundesministerium für Forschung und Technologie, Bonn, Germany.

\section{REFERENCES}

1. Andreesen, J. R., H. Bahl, and G. Gottschalk. 1989. Introduction to the physiology and biochemistry of the genus Clostridium, p. 27-62. In N. P. Minton and D. C. Clarke (ed.), Clostridia. Plenum Press, New York.

2. Axelsson, L., and S. Lindgren. 1987. Characterization and DNA homology of Lactobacillus strain isolated from pig intestine. J. Appl. Bacteriol. 67:433440 .

3. Barns, S. M., R. E. Fundynga, M. W. Jeffries, and N. R. Pace. 1994. Remarkable archae diversity in a Yellowstone National Park hot spring environment. Proc. Natl. Acad. Sci. USA 91:1609-1613.

4. Blomgren, A., A. Hansen, and B. H. Svensson. 1990. Enrichment of a mesophilic, syntrophic bacterial consortium converting acetate to methane at high ammonium concentrations, p. 225-234. In J. P. Belaich, M. Bruschi, and J.-L. Garcia (ed.), Microbiology and biochemistry of strict anaerobes involved in interspecies hydrogen transfer. Plenum Press, New York.

5. Boone, D. R., and M. P. Bryant. 1980. Propionate-degrading bacterium, Syntrophobacter wolinii sp. nov., gen. nov., from methanogenic ecosystems. Appl. Environ. Microbiol. 40:626-632.

6. Buck, J. D. 1982. Nonstaining (KOH) method for determination of Gram reactions of marine bacteria. Appl. Environ. Microbiol. 44:992-993.

7. Collins, M. D., P. A. Lawson, A. Willems, J. Cordoba, J. Fernandez-Garayzabal, P. Garcia, J. Cai, H. Hippe, and J. A. E. Farrow. 1994. The phylogeny of the genus Clostridium: proposal of five new genera and eleven new species combinations. Int. J. Syst. Bacteriol. 44:812-826.

8. De Soete, G. 1983 . A least squares algorithm for fitting additive trees to proximity data. Psychometrika 48:621-626.

9. Dolfing, J. 1988. Acetogenesis, p. 417-468. In A. J. B. Zehnder (ed.), Biology of anaerobic microorganisms. John Wiley and Sons, New York.

10. Gauglitz, U. 1988. Anaerober mikrobieller Abbau von Kreatin, Kreatinin und N-Methylhydantoin. Ph.D. thesis. Göttingen University, Göttingen, Germany.

11. Harrigan, W. F., and M. E. McCance. 1976. Laboratory methods in food and dairy microbiology. Academic Press, New York.

12. Hippe, H., J. R. Andreesen, and G. Gottschalk. 1992. The genus Clostridium-nonmedical, p. 1800-1878. In A. Balows, H. G. Trüper, M. Dworkin, W. Harder, and K.-H. Schleifer (ed.), The prokaryotes, 2nd ed. SpringerVerlag, New York.

13. Houwen, F. P., C. Dijkema, C. H. H. Schoenmakers, A. J. M. Stams, and A. J. B. Zehnder. 1987. ${ }^{13}$ C-NMR study of propionate degradation by a methanogenic coculture. FEMS Microbiol. Lett. 41:269-274.

14. Hungate, R. E. 1969. A roll tube method for cultivation of strict anaerobes. Methods Microbiol. 3B:117-132.

15. Jukes, T. H., and C. R. Cantor. 1969. Evolution of protein molecules, p. 21-132. In H. N. Munro (ed.), Mammalian protein metabolism. Academic Press, New York.

16. Kandler, O., K.-O. Stetter, and R. Köhl. 1980. Lactobacillus reuteri sp. nov., a new species of homofermentative lactobacilli. Zentralbl. Bakteriol. Micro- 
biol. Hyg. Abt. 1 Orig. C 1:264-269.

17. Kengen, S. W. M., and A. J. M. Stams. 1994. Formation of L-alanine as a reduced end product in carbohydrate fermentation by the hyperthermophilic archaeon Pyrococcus furiosus. Arch. Microbiol. 161:168-175.

18. Kovacs, N. 1965. Identification of Pseudomonas pyocyanea by the oxidase reaction. Nature (London) 178:703.

19. Lee, M. J. and S. H. Zinder. 1988. Isolation and characterization of a thermophilic bacterium which oxidizes acetate in syntrophic association with a methanogen and which grows acetogenically on $\mathrm{H}_{2}-\mathrm{CO}_{2}$. Appl. Environ. Microbiol. 54:124-129.

20. Lee, M. J., and S. H. Zinder. 1988. Carbon monoxide pathway enzyme activities in a thermophilic anaerobic bacterium grown acetogenically and in a syntrophic acetate-oxidizing coculture. Arch. Microbiol. 150:513-518.

21. Ljungdahl, L. G. 1986. The autotrophic pathway of acetate synthesis in acetogenic bacteria. Annu. Rev. Microbiol. 40:415-450.

22. Ljungdahl, L. G., J. Hugenholtz, and J. Wiegel. 1989. Acetogenic and acidproducing clostridia, p. 145-191. In N. P. Minton and D. C. Clarke (ed.), Clostridia. Plenum Press, New York.

23. MacLennan, J. D. 1939. The non-saccharolytic plectridial anaerobes. J. Pathol. Bacteriol. 49:535-548.

24. Marmur, J. 1961. A procedure for the isolation of deoxyribonucleic acid from microorganisms. J. Mol. Biol. 3:208-218.

25. McInerney, M. J., M. Bryant, R. B. Hespell, and J. W. Costerton. 1981. Syntrophomonas wolfei gen. nov., sp. nov., an anaerobic bacterium that degrades fatty acids in syntrophic association with methanogens. Appl. Environ. Microbiol. 41:1029-1039.

26. Niel, P., A. Rimbault, G. Campion, and G. Leluan. 1989. Phenotypic differentiation between Clostridium hastiforme and Clostridium subterminale by headspace gas chromatography. Int. J. Syst. Bacteriol. 39:491-492.

27. Örlygsson, J., F. P. Houwen, and B. H. Svensson. 1994. Anaerobic degradation of protein and the role of methane formation in steady state thermophilic enrichment cultures. Swed. J. Agric. Res. 23:45-54.

28. Petersen, S. P., and B. K. Ahring. 1991. Acetate oxidation in a thermophilic anaerobic sewage-sludge digestor: the importance of non-aceticlastic methanogenesis from acetate. FEMS Microbiol. Ecol. 86:149-158.

29. Peterson, G. L. 1983. Determination of total protein. Methods Enzymol. 91:91-119.

30. Pfennig, N. 1978. Rhodocyclus purpureus gen. nov. and sp. nov., a ring-shaped vitamin $\mathrm{B}_{12}$-requiring member of the family Rhodospirillaceae. Int. J. Syst. Bacteriol. 28:283-288.

31. Phelps, T. J., R. Conrad, and J. G. Zeikus. 1985. Sulfate-dependent interspecies $\mathrm{H}_{2}$ transfer between Methanosarcina barkeri and Desulfovibrio vulgaris during coculture metabolism on acetate or methanol. Appl. Environ. Microbiol. 50:589-594.

32. Rainey, F. A., M. Dorsch, H. W. Morgan, and E. Stackebrandt. 1992. 16S rDNA analysis of Spirochaeta thermophila: position and implications for the systematics of the order Spirochaetales. Syst. Appl. Microbiol. 16:224-226.

33. Rainey, F. A., and E. Stackebrandt. 1993. 16S rDNA analysis reveals phylo- genetic diversity among the polysaccharolytic clostridia. FEMS Microbiol. Lett. 113:125-128.

34. Rajagopal, B. S., and L. Daniels. 1986. Investigation of mercaptans, organic sulfides, and inorganic sulfur compounds as sulfur sources for the growth of methanogenic bacteria. Curr. Microbiol. 14:137-144.

35. Rimbault, A., P. Niel, H. Virelizier, J. C. Darbord, and G. Leluan. 1988. L-Methionine, a precursor of trace methane in some proteolytic clostridia. Appl. Environ. Microbiol. 54:1581-1586.

36. Rozanova, E, A. Galushko, and T. Nazina, 1990. An acetate-decomposing sulphidogenic syntrophic association, p. 469-470. In J. P. Belaich, M. Bruschi, and J.-L. Garcia (ed.), Microbiology and biochemistry of strict anaerobes involved in interspecies hydrogen transfer. Plenum Press, New York.

37. Schildkraut, C. L., and S. Lifson. 1965. Dependence of the melting temperature of DNA on salt concentration. Biopolymers 3:195-208.

38. Schink, B. 1992. Syntrophism among prokaryotes, p. 276-299. In A. Balows, H. G. Trüper, M. Dworkin, W. Harder, and K.-H. Schleifer (ed.), The prokaryotes, 2nd ed. Springer-Verlag, New York.

39. Schink, B. 1994. Diversity, ecology, and isolation of acetogenic bacteria, p. 197-235. In H. L. Drake (ed.), Acetogenesis. Chapman \& Hall, New York.

39a.Schnürer, A., B. H. Svensson, and B. Schink. Unpublished data.

40. Schnürer, A., F. H. Houwen, and B. H. Svensson. 1994. Mesophilic syntrophic acetate oxidation during methane formation by a triculture at high ammonium concentration. Arch. Microbiol. 162:70-74.

41. Schnürer, A., G. Zellner, and B. H. Svensson. Unpublished data.

42. Schweiger, G., and W. Buckel. 1985. Identification of acrylate, the product of dehydration of (R)-lactate catalysed by cell-free extracts from Clostridium propionicum. FEBS Lett. 185:253-256.

43. Stieb, M., and B. Schink. 1985. Anaerobic oxidation of fatty acids by Clostridium bryantii sp. nov., a sporeforming, obligately syntrophic bacterium. Arch. Microbiol. 140:387-390.

44. Whitmer, M. E., and E. A. Johnsson. 1988. Development of improved defined media for Clostridium botulinum serotypes A, B, and E. Appl. Environ. Microbiol. 54:753-759.

45. Widdel, F., G. W. Kohring, and F. Mayer. 1983. Studies on dissimilatory sulfate-reducing bacteria that decompose fatty acids. III. Characterization of the filamentous gliding Desulfonema limnicola gen. nov. sp. nov., and Desulfonema magnum sp. nov. Arch. Microbiol. 134:286-294.

46. Widdel, F., and N. Pfennig. 1981. Studies on dissimilatory sulfate-reducing bacteria that decompose fatty acids. I. Isolation of new sulfate-reducing bacteria enriched with acetate from saline environments. Description of Desulfobacter postgatei gen. nov., sp. nov. Arch. Microbiol. 129:395-400.

47. Zehnder, A. J. B., B. A. Huser, T. D. Brock, and K. Wuhrmann. 1980. Characterization of an acetate-decarboxylating, non-hydrogen-oxidizing methane bacterium. Arch. Microbiol. 124:1-11.

48. Zinder, S. H., and M. Koch. 1984. Non-aceticlastic methanogenesis from acetate: acetate oxidation by a thermophilic syntrophic coculture. Arch. Microbiol. 138:263-272. 